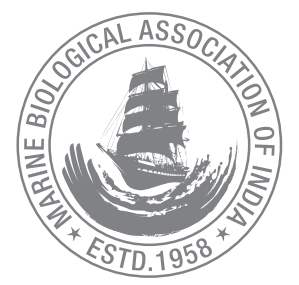

\title{
Ontogenetic changes in morphometry of the spiny lobster, Panulirus homarus homarus (Linnaeus, 1758) from southern Indian coast
}

\author{
E.V. Radhakrishnan*, R. Thangaraja and M. Vijayakumaran' \\ Central Marine Fisheries Research Institute, Post Box No. 1603, Kochi - 682018, Kerala, India. \\ ${ }^{1}$ National Institute of Ocean Technology, Pallikaranai, Chennai - 600 100, India. \\ *Correspondence e-mail: evrkrishnan@yahoo.com
}

Received: 07 Jul 2014, Accepted: 06 Feb 2015, Published: 15 Mar 2015

Original Article

\begin{abstract}
The morphometric relationships, carapace length vs total length $(\mathrm{CL}$ vs $\mathrm{TL})$, carapace length vs weight ( $\mathrm{CL}$ vs $\mathrm{W})$, total length vs weight (TL vs W), carapace length vs carapace width (CL vs CW), carapace length vs length of third walking leg (CL vs III WL) and carapace length vs width of second abdomen (CL vs II ASW) were estimated for the Scalloped spiny lobster Panulirus homarus homarus fished from east and west coast of Tamilnadu. A total of 462 males and 350 females were measured for the study. Carapace length of lobsters ranged from $20.4 \mathrm{~mm}$ to 101.0 mm CL. The power function $y=a x^{b}$ was applied in all the relationships. The first derivative $\mathrm{dY} / \mathrm{dCL}-\mathrm{abCL} \mathrm{b}-1$ where $\mathrm{Y}$ is $\mathrm{TL}$ was used to study the growth tendency of $T L$ in relation to $C L$. A negative allometry, $b<1$ was found for males which was also reflected in their decreasing growth rate of TL in relation to CL. The $C L$ vs W relationship showed a general negative allometry, $b<3$ in both sexes. Size at the onset of sexual maturity in male was determined based on allometric growth of third pereopod. Slopes of regression of log transformed data showed positive allometric growth of third pereopod for males $(b=1.17)$ compared to negative allometry in females $(b=0.97)$. Females had $(b=1.04)$ positive allometry in second abdomen width compared to negative allometry in males $(b=0.934)$. However, their size at maturity could not be precisely predicted as the $b$ value of the two regression lines of immature (1.09) and mature females (1.01) did not indicate any significant deviation from 1. The size at maturity of males $(63.0 \mathrm{~mm})$ was determined where the two regression lines of mature and immature specimens crossed. The results obtained in the present study support the
\end{abstract}

predictions of resource allocation theory in crustaceans and demonstrate marked shifts in resource allocation through ontogeny in both sexes.

Keywords: Panulirus homarus homarus, morphometry, allometry, growth rate, size at maturity

\section{Introduction}

P. homarus is a high value crustacean resource and mostly exported as live as well as in processed form. Three subspecies have been recognised based on colour and the abdominal sculpta (Berry, 1974; Holthuis, 1991). The subspecies $P$. homarus homarus is distributed throughout the Indo-West Pacific region where it is found generally among rocks in the surf zones in shallow waters (mostly 1-5 m) (Holthuis, 1991). However, their distributional depth range is between 1-90 $\mathrm{m}$. P. homarus rubellus has a restricted distribution along the east coasts of South Africa, Mozambique and Madagascar (Holthuis, 1991) and P. homarus megasculpta is only found 
from the northern Arabian Sea and Somalia (Fielding and Mann, 1999). Morphological and genetic studies show that $P$. homarus homarus is the only subspecies distributed along the Indian coast (Jeena, 2013). The Scalloped spiny lobster Panulirus homarus homarus (Linnaeus, 1758) is widely distributed in coastal waters of India but forms fishery mainly along the southwest and southeast coasts of India.Though morphometric relationships have been worked out for the subspecies $P$. homarus rubellus in South Africa (Berry, 1971) and $P$. homarus megasculpta in Sultanate of Oman (Al-Marzouqi et al., 2007) and P. homarus homarus from Sri Lanka (Jayakody, 1989) and Kenya (Kulmiye et al, 2006), no comprehensive studies have been carried out on P. homarus homarus from India, especially the allometric changes in body proportions in relation to sexual maturity. Morphological relationships have been described for Panulirus polyphagus (Kagwade, 1987; Kizhakudan and Patel, 2010), P. versicolor (Vaitheeswaran et al., 2012) and Thenus orientalis (Kabli and Kagwade, 1996; Saha et al., 2009). All the above authors when studying the relationship of carapace length $(\mathrm{CL})$ vs total length $(\mathrm{TL})$ considered the growth of TL directly proportional (isometric growth) to the growth of $\mathrm{CL}$ using the linear model $\mathrm{TL}=\mathrm{a}+(\mathrm{b} \subset \mathrm{L})$ in which $\mathrm{b}$ is considered at a constant rate of increase. However, Minos et al. (1995) and Tidu et al. (2004) applied the exponential equation $Y=a x^{b}$ when $b=1$ to explain the relationship of CL vs TL as they believed that in nature the constant rate of increase of any morphometric character is a specific feature of the differential increase in these two body dimensions. There are no management regulations governing the harvest of spiny lobsters in India, except for the minimum legal size restrictions for export (Radhakrishnan and Manisseri, 2003). The knowledge of the relationship on $\mathrm{CL}$ vs weight $(\mathrm{W})$ may be useful as the minimum legal size for $P$. homarus homarus is usually expressed as W which is not considered as the standard measurement to determine the legal size.

Determining the size at onset of sexual maturity is important in the management of the resource especially for considering minimum legal size at capture (Kulmiye et al., 2006). In decapods, gonad maturity (physiological maturity), behavioural maturity (functional maturity) and sex specific allometric growth (morphological maturity) may occur at different stages (Hartnoll, 1982 and Hall et al., 2006). Jones (2007) stated that morphometric differentiation between sexes in lobsters was related most noticeably to characteristics associated with sexual maturity. The sex-specific allometric growth can be estimated by several methods, including changes in the relative size of abdominal and thoracic segments (Jayakody, 1989) or length of walking legs or pleopodal exopodites (Juinio, 1987; Gomez et al. 1994; Minagawa and Higuchi, 1997; De Martini et al. 2003; Kulmiye et al., 2006). In spiny lobsters, males exhibit positive allometric growth of II and III pereopods whereas females show positive allometric growth in abdomen width (Berry, 1971; Minagawa and Higuchi, 1997; Kizhakudan and Patel, 2010). Greater abdominal width in females is considered to be an adaptation for increasing reproductive outputs and positive allometry in II and III male pereiopod length is hypothesized to be an adaptation for intrasexual competition or mating success for males (Farmer, 1974; Hartnoll, 1974; Lipcius et al., 1983; Smith et al., 1994; Claverie and Smith, 2009) for which energy allocation is augmented with increasing body size. Body structures relevant for searching, guarding or choosing sexual partners become positively allometric and possibly sexually dimorphic at the onset of sexual maturity (Crawford and De Smidt, 1922; Lipicus et al., 1983; Anderson et al., 2013).

The paper describes ontogenetic changes in relative growth of body parts of six body dimensions of female and male $P$. homarus homarus and an attempt has also been made to estimate the onset of sexual maturity on the basis of relationship between $\mathrm{CL}$ and length of third walking leg (III $\mathrm{WL}$ ) in males and $\mathrm{CL}$ and second abdominal segment width (IIASW) in females.

\section{Material and methods}

The spiny lobster $P$. homarus homarus caught by bottomset-gillnets and trammel nets during the fishing season (September 2006 to February 2008) from lobster fishing centers at Khadiyapatanam (Lat: $8^{\circ} 07^{\prime} \mathrm{N}$, Long: $77^{\circ} 18^{\prime} \mathrm{E}$ ), Chinnamuttom (Lat: $8^{\circ} 05^{\prime} \mathrm{N}$, Long: 77033' E) and Kovalam near Chennai ( Lat: $12^{\circ} 47^{\prime}$ Long: $80^{\circ} 15^{\prime} \mathrm{E}$ ) along the southern coast of India were sampled.

For morphometric analysis, male and female $P$. homarus homarus were categorised and the body dimensions $\mathrm{CL}$, carapace width (CW), TL, II ASW, W and III WL recorded. The lobsters were flattened before TL was recorded following Hepper's (Hepper,1966) methodology. The $\mathrm{CL}(\mathrm{mm})$ was measured as the distance along the dorsal midline between the supraorbital horns to the posterior extremity of the cephalothorax and total length from the anterior margin of the carapace to the end of the telson. The carapace length was measured using a vernier caliper to an accuracy of 0.1 $\mathrm{mm}$ and total length by using a half metre scale to the nearest $1 \mathrm{~mm}$ and weight using a portable weighing balance (AND GF-3000) to an accuracy of $1 \mathrm{~g}$. The relationships CL vs TL, $\mathrm{CL}$ vs $\mathrm{W}, \mathrm{CL}$ vs $\mathrm{CW}$, $\mathrm{TL}$ vs $\mathrm{W}, \mathrm{CL}$ vs II $\mathrm{ASW}$ and $\mathrm{CL}$ vs length of III WL were estimated using the power function $y=a x b$. The parameters of the equations were estimated by least square regression following logarithimic transformation. For each of the relationships, $t$-test (Zar, 1999) was performed 
to find if there was a significant deviation of $b$ (the slope) from the expected slope of unity $(b=1)$ for $C L$ vs $T L, C L$ vs $C W, C L$ vs IIASW and $C L$ vs IIIWL and 3 for $C L$ vs $W$ and TL vs W. Differential growth rate of CL vs TL between the sexes was obtained from the power function $y=a x^{b}$ using the first derivative in relation to $\mathrm{CL}: \mathrm{dY} / \mathrm{dCL}=\mathrm{abCL} b^{-1}$, where $a$ and $b$ are constants and $Y$ is derivative of TL. All statistical analysis was carried out using MS Excel 2003 and SPSS software version 13.0.

\section{Allometric growth}

In order to assess whether the morphological structures related to reproduction (length of third pereiopod in males and second abdomen segment width in females) grew proportionally (linearly) with a unit increase in body size in male and female P. homarus homarus and also to assess ontogenetic changes in growth pattern of these morphological parts from juvenile to adult, the allometry equation $y=a x^{b}$ (Hartnoll, 1978) was applied. The slope $b$ of the log-log least squares linear regression represents positive allometric $(b>1)$ isometric $(b=1)$ or negative allometric $(b<1)$ growth of structure relative to body size (Hartnoll, 1978). To assess deviation from linearity, $t$-test was applied to determine whether the observed slope deviated significantly from the expected slope of unity $(b=1)$. To investigate the existence of a transitional $\mathrm{CL}$ (a discontinuity in relative growth) indicating the size at morphological sexual maturity, the length of the third walking leg in males and the width of the second abdomen segment for females were regressed against $\mathrm{CL}$. The iterative segmental regression method of Lovett and Felder (1989) was applied to identify the transitional $\mathrm{CL}$ for which log transformed data were used. The transitional point is defined as the resulting lowest combined sum of square residuals (SSR) of the two subset regressions. 'This transition point was the midpoint of the size range over which resource allocation shift with ontogenetic phase (Lovett and Felder, 1989). Allometry was assessed by testing whether the proportionality constant differ significantly from 1 with student's $t$-test (Zar, 1999). The probable size at maturity was also determined by plotting the length of third pereiopod against the $\mathrm{CL}$ for (mature and immature size) males and second abdomen segment width against $\mathrm{CL}$ for females and the point of intersection of the two regression lines was taken as the size at functional maturity (George and Morgan, 1979).

\section{Results}

\section{Population structure}

In total 350 females and 462 male lobsters were sampled during the study, ranging in size from $20.4 \mathrm{~mm}$ to $101.1 \mathrm{~mm}$
$\mathrm{CL}$. The average carapace length of female lobsters was $49.1 \pm 13.9$ and that of males $49.4 \pm 12.4 \mathrm{~mm}$. The lower mean length of lobsters was due to large number of lobsters in the group of $40-70 \mathrm{~mm} \mathrm{CL}$ range. The length distribution for females and males used in the morphometric study are presented in Fig. 1.

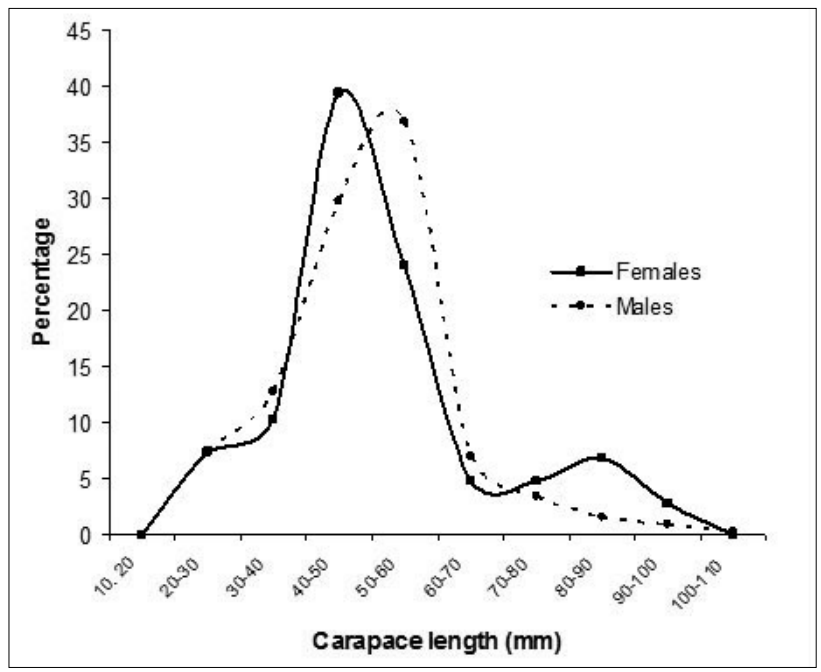

Fig 1. Size distribution of male and female $P$. homarus homarus.

In females $50-60 \mathrm{~mm} \mathrm{CL}$ accounted for $40 \%$ of the total numbers sampled. For males $40-50 \mathrm{~mm}$ and $50-60 \mathrm{~mm} \mathrm{CL}$ lobsters accounted for nearly $55 \%$ of the population sampled. Females dominated the larger size group.

The parameter of the relationship of $\mathrm{CL}$ with other body structures is shown in Table 1. Both males and females displayed a constant growth rate relationship with $\mathrm{CL}$ in CL-TL, CL-CW, CL-W and TL-W measurements. The regression slope of the relationship between $\mathrm{CL}$ and $\mathrm{TL}$ in females was not significantly different from $1(b=1.008$, $p>0.05$ ) showing the growth rate of TL isometric, whereas the slope in males was significantly smaller than $1(b=0.9278, p<0.05)$ to be negatively allometric (Table 1). The total length of females was shorter in juveniles up to $40 \mathrm{~mm} \mathrm{CL}$ and greater beyond $50 \mathrm{~mm} \mathrm{CL} \mathrm{(Fig.2).} \mathrm{This}$ is indicative of the females having a greater total length for a given carapace length especially at larger sizes. The regression slope of the relationship between $\mathrm{CL}$ and $\mathrm{CW}$ in female was isometric $(b=1.0042, P>0.05)$ whereas the slope in male was negatively allometric $(b=0.9747$, $\mathrm{P}<0.05$ ) (Fig.3), showing wider $\mathrm{CW}$ in females compared to males. The growth rate of TL in relation to CL was calculated by means of the first derivative for both sexes. In females, the growth rate of $T L$ in relation to $C L$ was greater than males and constant (isometric growth), whereas in males a decreasing growth rate (negative allometry) was observed (Fig.4). 


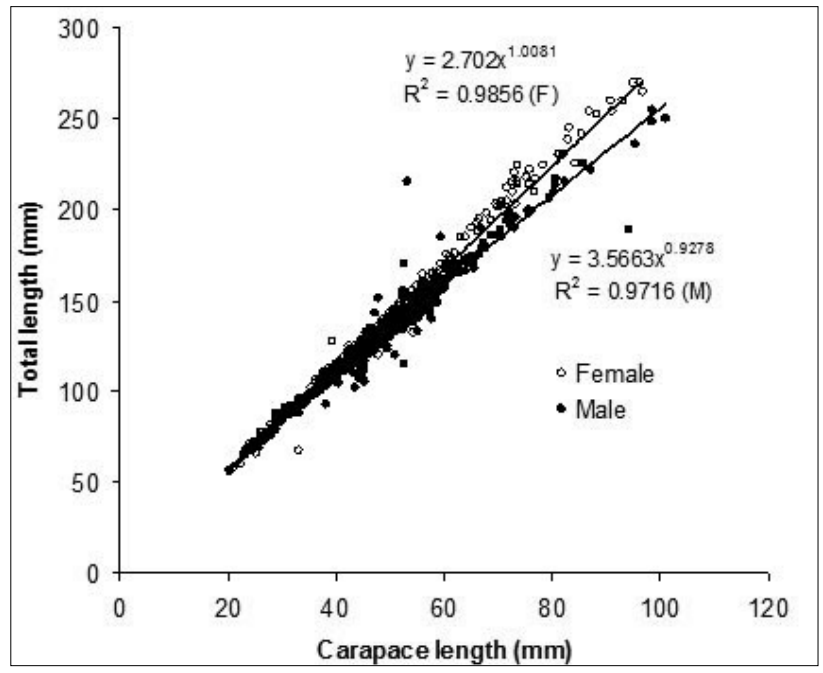

Fig 2. Relationship between carapace length and total length in P. homarus homarus.

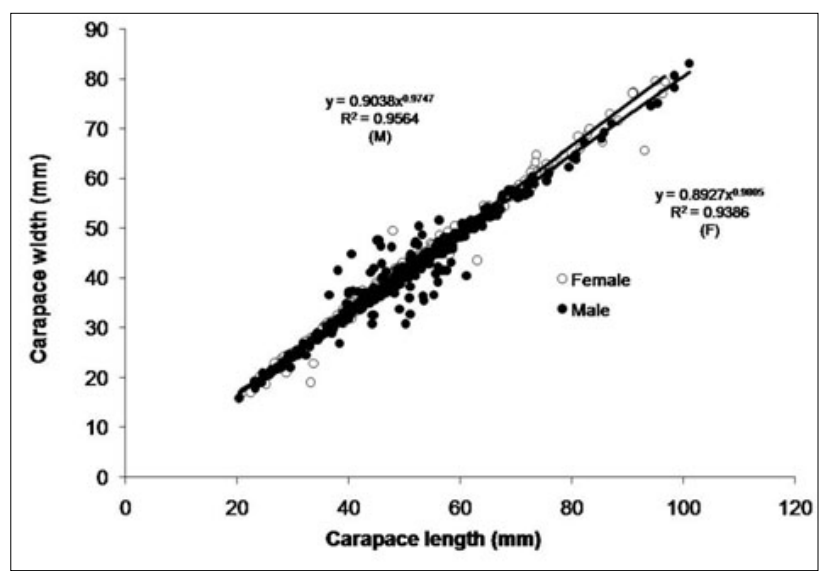

Fig 3. Relationship between carapace length and carapace width in P. homarus homarus.

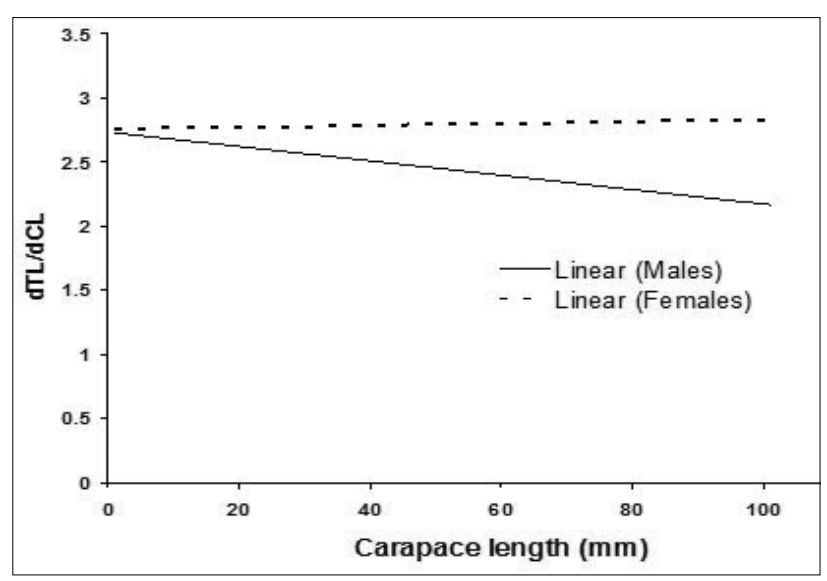

Fig 4. Growth rate of male and female P. homarus homarus.

The parameters of the relationship CL vs W (Table 1) shows that the slopes were significantly different from 3 in both males and females $(p<0.05)$ (Fig. 5$)$ and is indicative of

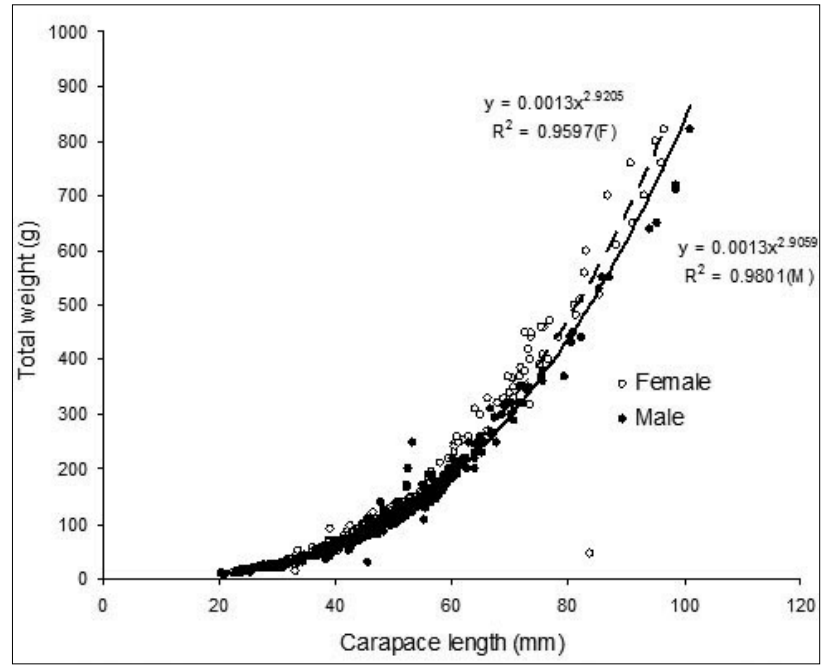

Fig 5. Relationship between carapace length and total weight in P. homarus homarus.

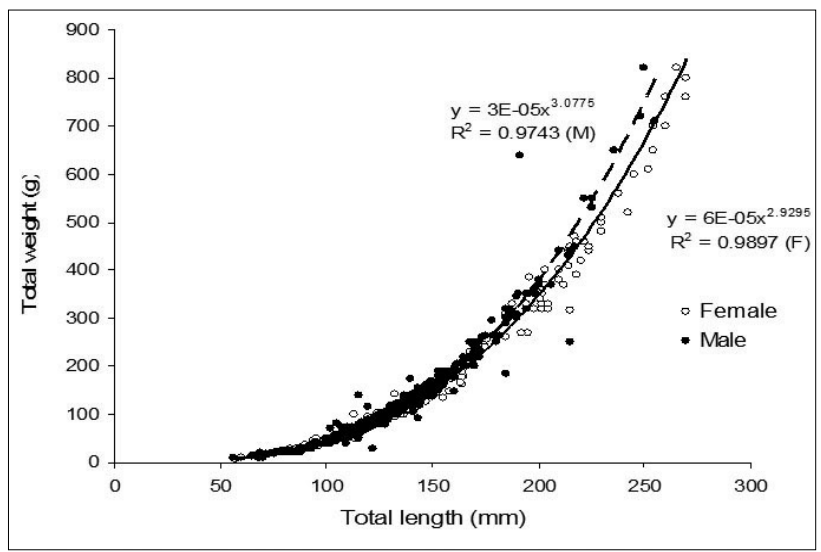

Fig 6. Relationship between total length and total weight in $P$. homarus homarus

the general negative allometry in both sexes. The inter-sex comparison, on the other hand, shows significant difference in the slope between male and female lobsters $(p<0.05)$ (Table 1). The higher slope value in female $(b=2.92)$ indicate faster growth rate of $W$ in females (Table 1) especially at larger sizes. The relationship of TL vs W, on the other hand, gives a different picture showing positive allometry with $b$ value more than 3 in males $\left(b_{\text {females }}=2.929, b_{\text {males }}=3.078\right)$, which is significantly different compared to females (ANCOVA, $\mathrm{p}<0.005$ ) (Fig.6).

\section{Morphological determination of the onset of sexual maturity}

The relationship of third walking leg length (IIIWL) and second abdominal segment width (IIASW) to CL for males and females, respectively, indicates allometric relationship in both sexes. Slopes of regression of the log-transformed data showed positive allometric growth of IIIWL in males $(b=1.17$, 


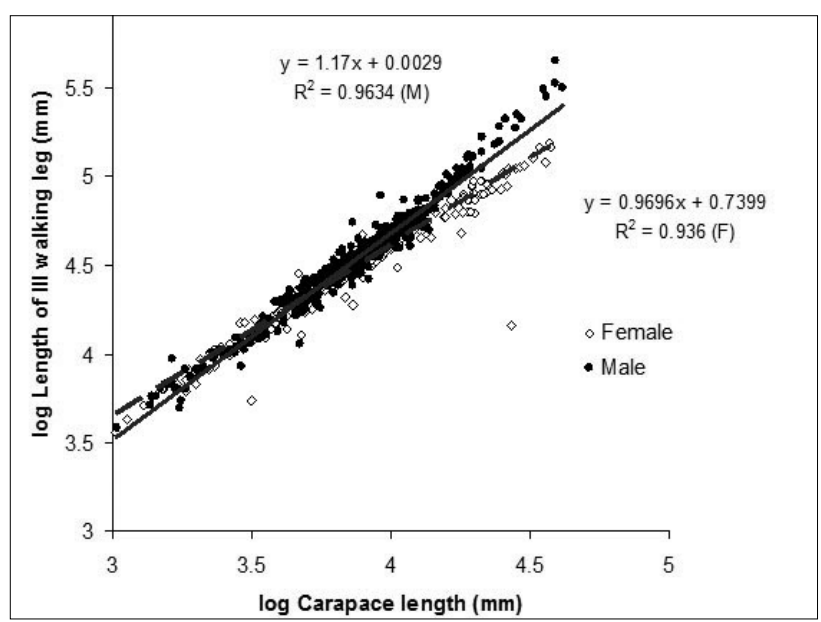

Fig 7. Relationship between carapace length and length of III walking leg in $P$. homarus homarus

$p<0.05)$ but negative allometry in females $(b=0.936$, $\mathrm{p}<0.05$ ) (Fig 7). The analysis demonstrated the existence of a relationship between $\mathrm{CL}$ and length of III walking leg in males that include two growth phases separated by a transitional $\mathrm{CL}$. During the first ontogenetic phase (immature), males exhibited isometric growth of the IIIWL $(b=1.09, p<0.05)$, although the same structure was strongly positively allometric

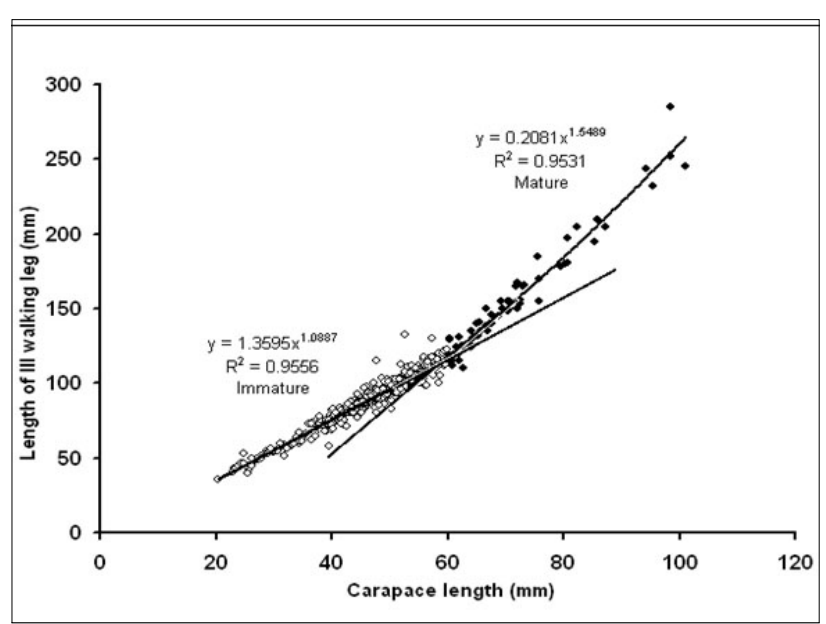

Fig 8. Relationship between carapace length and length of III walking leg of immature and mature males in P. homarus homarus

during the second phase (mature) $(b=1.55, p<0.05)$ (Table 1). The two regression lines on extension crossed at 63.0 $\mathrm{mm} \mathrm{CL}$, the same transitional point $(63.0 \mathrm{~mm} \mathrm{CL})$ which was obtained using the protocol developed by Lovett and Felder (1989) (Fig.8). This transitional point was the midpoint of the size range over which resource allocation shift with ontogenetic phase and is considered to be the size at onset

Table 1. Regression parameters of $P$. homarus homarus and significance between slopes

\begin{tabular}{|c|c|c|c|c|c|c|}
\hline Relationship & $r^{2}$ & Sex & Regression equations & $\mathrm{A} / \mathrm{l}$ & $\mathrm{N}$ & ANCOVA (p) \\
\hline \multirow{2}{*}{$\begin{array}{l}\text { Carapace length } \\
\text { vs. Total length }\end{array}$} & 0.9856 & M & $\mathrm{TL}=3.5663 \mathrm{CL} 0.9276$ & $-A$ & 462 & \\
\hline & 0.9716 & $\mathrm{~F}$ & $\mathrm{TL}=2.702 \mathrm{CL} 1.0081$ & 1 & 350 & $1.95 \mathrm{E}-12$ \\
\hline \multirow{2}{*}{$\begin{array}{l}\text { Carapace length } \\
\text { vs. Total weight }\end{array}$} & 0.9800 & M & $W=0.0012 C L 2.9058$ & $-A$ & 462 & \\
\hline & 0.9597 & $\mathrm{~F}$ & $W=0.0013 C L 2.9605$ & $-A$ & 350 & $1.61 \mathrm{E}-05$ \\
\hline \multirow{2}{*}{$\begin{array}{l}\text { Total length } \\
\text { vs Total weight }\end{array}$} & 0.9741 & $\mathrm{M}$ & $W=3.13 \mathrm{E}-05$ TL3.0776 & $+\mathrm{A}$ & 462 & 0.00035 \\
\hline & 0.9896 & $\mathrm{~F}$ & $\mathrm{~W}=6.32 \mathrm{E}-05$ TL2.9205 & $-A$ & 350 & \\
\hline \multirow{2}{*}{$\begin{array}{l}\text { Carapace length } \\
\text { vs Carapace width }\end{array}$} & 0.9564 & M & $C W=-0.9038 C L 0.9747$ & $-A$ & & 0.021 \\
\hline & 0.983 & $\mathrm{~F}$ & $C W=-0.0 .8927 C L 0.9605$ & $-A$ & & \\
\hline \multirow{2}{*}{$\begin{array}{l}\text { Carapace length } \\
\text { vs. IInd abdomen segment width }\end{array}$} & 0.9639 & M & $A W=0.877 C L 0.9336$ & $-A$ & 462 & \\
\hline & 0.9587 & $\mathrm{~F}$ & $A W=0.6102 C L 1.043$ & $+\mathrm{A}$ & 350 & $2.72 \mathrm{E}-16$ \\
\hline $\begin{array}{l}\text { Carapace length vs. IInd abdomen segment } \\
\text { width (Immature) }\end{array}$ & 0.8749 & $\mathrm{~F}$ & $A W=0.514 C L 1.090$ & $+\mathrm{A}$ & 125 & 0.00021 \\
\hline $\begin{array}{l}\text { Carapace length vs. IInd abdomen segment } \\
\text { width (Mature) }\end{array}$ & 0.9394 & $\mathrm{~F}$ & $A W=0.6935 \mathrm{ICL} 1.011$ & I & 221 & \\
\hline \multirow{2}{*}{$\begin{array}{l}\text { Carapace length } \\
\text { vs. length of IIIrd walking leg }\end{array}$} & 0.9634 & M & $\mathrm{IIIWL}=1.0029 \mathrm{CL} 1.17$ & $+\mathrm{A}$ & 462 & $1.64 \mathrm{E}-133$ \\
\hline & 0.8771 & $\mathrm{~F}$ & IIIWL=2.2198CL0.9634 & $-A$ & 350 & \\
\hline $\begin{array}{l}\text { Carapace length vs. length oflllrd walking leg } \\
\text { (Immature) }\end{array}$ & 0.9556 & M & IIIWL=2.403CL1.088 & I & 398 & $2.27 \mathrm{E}-11$ \\
\hline $\begin{array}{l}\text { Carapace length vs. length of Illrd walking } \\
\text { leg (Mature) }\end{array}$ & 0.9531 & M & $\mathrm{IIIWL}=0.2081 \mathrm{CL} 1.548$ & $+\mathrm{A}$ & 59 & \\
\hline
\end{tabular}

Homogeneity of slopes between the sexes was rejected at $p=<0.005$ (ANCOVA)

$+A$ - indicate positive allometry $(p=<0.05)$, $-A$ - indicate negative allometry $(p=<0.05)$, I- indicates Isometry $(p=>0.05)$ (Isometry was tested following t- test departure from 3 for $W$ and 1 for other length relationships in power equation) 


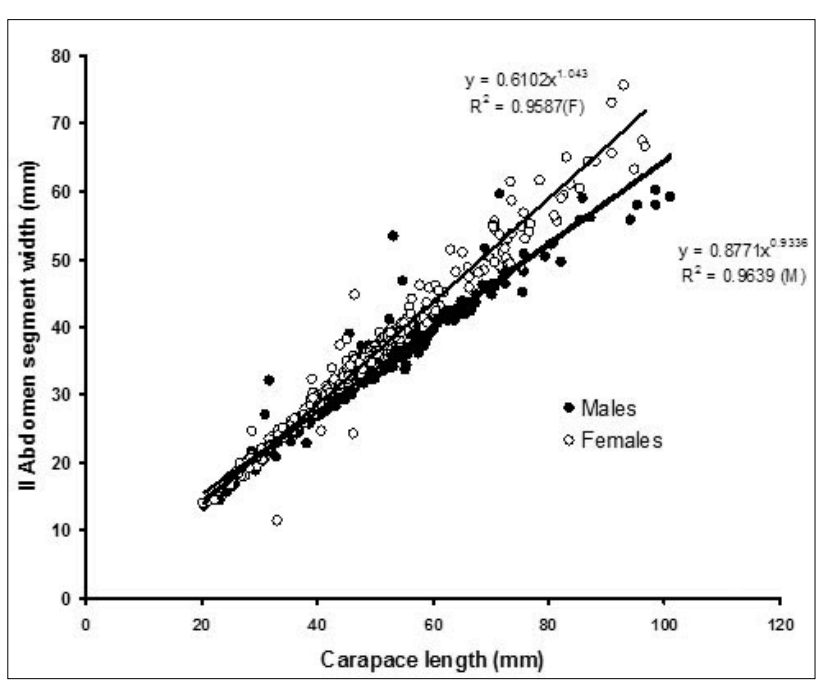

Fig 9. Relationship between carapace length and second abdomen segment width in $P$. homarus homarus

of sexual maturity in males. The slopes of the two regressions between $\mathrm{CL}$ and IIIWL was significantly different between the immature and mature males $(p=<0.005$, ANCOVA). Slope of regressions of the log transformed data of $C L$ and IIASW showed positive allometric growth in IIASW $(b=1.04$, $p<0.05)$ in females which was negatively allometric in males $(b=0.93, p<0.05)$ (Fig.9). The immature females had positive allometric $(b=1.09, p<0.05)$ growth of the second abdomen width than females of mature size, which was isometric $(b=1.01)$ (Fig.10). The morphological size (transitional $\mathrm{CL})$ at maturity determined by the protocol developed by Lovett and Felder (1989) for females ( $35 \mathrm{~mm} \mathrm{CL}$ ) is doubtful as the $50 \%$ size at maturity determined by the relationship between length of endopod setae and $C L$ and percentage of ovigerous females vs $\mathrm{CL}$ were larger $(53.0 \mathrm{~mm}$ and $61.0 \mathrm{~mm}$ CL) (Thangaraja, 2011).

\section{Discussion}

Many previous studies have established morphometric variability by comparing various body dimensions and carapace length using linear regression and power function equations. Carapace length was shown to be the most accurate and precise index of size out of the morphometric dimensions examined because it represents the physiological changes that occur over their life history (Jones, 2007). The results show that increase in total length in relation to carapace length is greater in females especially at the size above maturity, which is believed to be a common general trait in spiny lobsters (Tidu et al., 2004, Sanders and Liyanage, 2009). The higher total length in females may be due to longer tail length (abdomen length). The longer abdomen in females facilitates a relatively longer telson assisting physical protection of eggs carried in their abdomen region. Thus

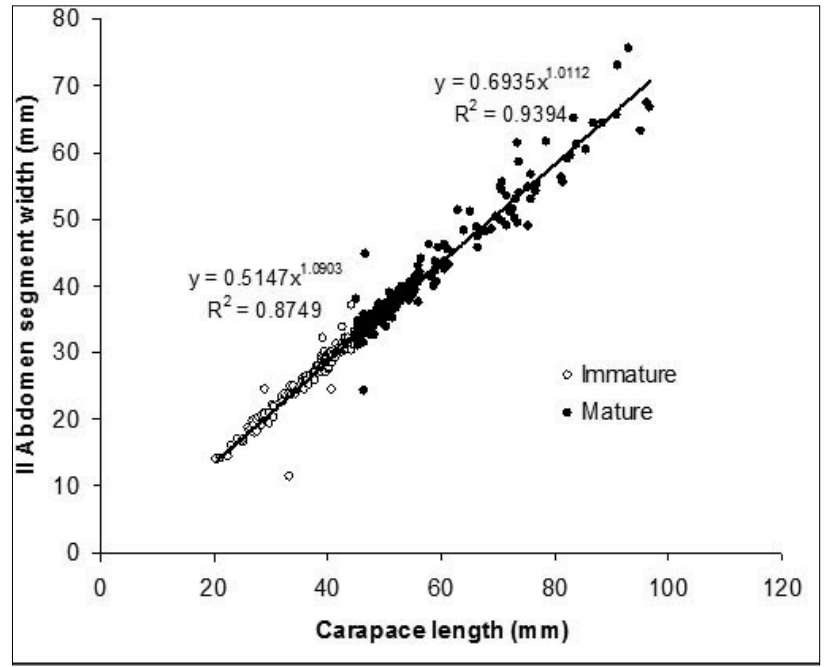

Fig 10. Relationship between carapace length and second abdomen segment width in immature and mature females in P. homarus homarus

the greater mean size of females may be associated with egg carrying capacity and the maximization of reproductive efficiency (Jones, 2007). The results obtained in the present study also conform closely with the linear regression calculated for CL-TL relationship for $P$. homarus distributed off South African (Berry, 1971) and Sri Lankan waters (Jayakody, 1989). Tidu et al. (2004) demonstrated negative allometry for males of Panulirus elephas and suggested the use of power function $y=a x^{b}$ a better model than the linear model that yield an isometric growth: $y=a+b x$. The advantage of using power function to study the CL-TL relationship is that the difference in growth rate between the two sexes could be clearly broughtout. In the present study, negative allometry for males in the relationship of $\mathrm{CL}$ vs TL reflected in the decreasing growth rate of $\mathrm{TL}$ in relation to $\mathrm{CL}$. The faster TL growth rate in females therefore explaines the longer TL for equal carapace length. Isometry in carapace width was observed in females but with a lower relative growth rate in males initialy and no signifiant difference in carapace width at larger sizes in both sexes. Wide variability in carapace of males was noticed especially in sizes approaching maturity. Kizhakudan and Patel (2010) also reported wider carapace in females compared to males of $P$. polyphagus.

Many previous studies on CL-W relationship have shown negative allometry $(b<3)$ in majority of lobster species (Berry, 1971; Kabli and Kagwade, 1996; Tidu et al., 2004; Al-Marzouqi et al., 2007). The negative allometry obtained in the present study is similar to the result obtained for $P$. homarus fished in other regions (Heydorn, 1969; Berry, 1971; Al-Marzouqi et al., 2007) except for the Sri Lankan population in which males are heavier compared to females (Table 2). The proportionality constant for females in the present study $(b=2.9)$ is higher as the abdomen of the females is heavier 
Table 2. Regression slope ' $b$ ' value obtained for the relationship between carapace length $(\mathrm{CL})$ and weight $(\mathrm{W})$ in Panulirus homarus for different geographic regions

\begin{tabular}{lll}
\hline Geographic region & Author and year & b value \\
\hline South Africa & Berry, 1971 & Male $: 2.7767$ \\
\cline { 3 - 3 } Oman & Al-Marzouqi et al. 2007 & Female :2.8590 \\
\hline Sri Lanka & Sanders and Liyanage, 2009 $: 2.717$ \\
\hline \multirow{2}{*}{ India (Present study) } & Radhakrishnan et al. & Male $: 2.71$ \\
\hline
\end{tabular}

which is evident from the longer tail length and wider abdomen in females (Berry, 1971, Kagwade, 1987, Tidu et al., 2004, Al-Marzouqi et al., 2007). In majority of spiny lobsters, for an equal carapace length, females are heavier than males especially beyond maturity and thus dimorphism has been related to egg bearing in females (Heydorn, 1969).

The $b$ value obtained for males in TL-W relationship, on the other hand, was greater than the value obtained for males using CL-W relationship. Higher b value has been reported for Sri Lankan population of male $P$. longipes $(b=3.05$ for males and 2. 98 for females) and $P$. penicillatus ( $b=3.32$ for males and 2.62 for females) (Sanders and Liyanage, 2009). The spiny lobster $P$. polyphagus also exhibits similar trend in TL-W relationship especially at the adult stage (Kagwade, 1987). Though total length is used by these authors for estimating length-weight relationship, carapace length is the main morphometric dimension used as an independent variable in morphometric analysis of lobsters and hence carapace length is recommended as the standard length for establishing lengthweight relationship in spiny lobsters. However, morphometric studies in the mud spiny lobster $P$. polyphagus and the slipper lobster Thenus orientalis have mostly used total length for estimating length-weight relationships (Kagwade, 1987; Kabli and Kagwade, 1996; Saha et al., 2009). The 'b' values obtained were less than 3 in females, but greater in males of $P$. polyphagus. However, b value was higher in females than males of the same total length in $T$. orientalis.

Although the CL-TL, CL-W and TL-W relationships examined in the present study displayed a single growth phase through ontogeny, other morphometric structure such as the third walking leg in males experienced substantial shift in relative growth indicating the existence of more than a single ontogenetic phase in $P$. homarus homarus. Positive allometry in third walking leg length was observed over the entire size range of males examined in the present study with a sudden shift over a narrow size range indicating the existence of two ontogenetic phases in $P$. homarus homarus. Spider crabs are commonly known to exhibit three ontogenetic phases in their life history (Hartnoll, 1974, 1978). Many previous studies have identified such discontinuity in the relative growth rate of crustacean body parts such as first pleopod length and abdomen width in females and leg length in males (Berry, 1971; Hartnoll, 1974, 1982; Tidu et al. 2004; Kulmiye et al. 2006; Claverie and Smith, 2009).

Our results indicated ontogenetic shift in growth rate of third walking leg at $63.0 \mathrm{~mm} \mathrm{CL}$ in males (the intersection point of immature and mature regression lines) (Fig.8) which was considered to be the size at morphological (physical) maturity in $P$. homarus homarus. No male gonad index was available to verify the relative change in the leg length to attainment of physiological maturity. Kulmiye et al. (2006) showed a close relationship between increasing second walking leg length and carapace length in male $P$. homarus homarus for Kenyan waters. The presumed size at maturity was $57.5 \mathrm{~mm}$ $\mathrm{CL}$ derived from the intersection line of immature and mature lobsters. Berry (1971) observed diversion of the male and female leg length at a carapace length of $55 \mathrm{~mm}$ in $P$. homarus rubellus from the South African coast. Further on observation of seminal fluid, spermatozoa were found in animals from $47 \mathrm{~mm} \mathrm{CL}$ upwards and he concluded that males are capable of mating between carapace length of $55-59 \mathrm{~mm}$ which is in conformity with the observation made by Heydorn (1969) in P. homarus from Transkeian waters. The males may have to attain a considerably larger size than the size of physiological maturity before they can physically mate with a female. Captive P. homarus rubellus has been observed to use their front walking legs during dominance display and mating (Berry, 1970). Positive allometry in abdomen width was found for the entire size range of females but was more pronounced during the early ontogenetic phase. This transition from positive allometry to isometry of the abdomen width at maturity could be explained by a change in energy allocation (Claverie and Smith, 2009). Morphometric analysis of secondary sexual characters in spiny lobsters, spider crabs and squat lobsters have identified shifts in resource allocation during ontogeny around the onset of sexual maturity (Hartnoll, 1965, 1974; Berry, 1971; Kulmiye et al., 2006; Berke and Woodin, 2008; Anderson et al., 2013). The slower allometric abdominal growth rate in mature females may be a strategy to allocate more energy sources in egg production. Such ontogenetic shifts in resource allocation for reproductive structures around the onset of sexual maturity are well documented for the spiny lobster $P$. argus (Anderson et al., 2013) and the squat lobster Munida rugosa (Claverie and Smith, 2009). The shift in the level of allometry during the mature phase is probably related to the fact that the ovaries does not act independently 
like the walking legs. However, the body size at which the shift in abdominal allometry occurred was smaller $(35 \mathrm{~mm} \mathrm{CL}$ onwards) than the estimates of size at first maturity based on the relationship between length of endopod setae $(53.0$ $\mathrm{mm} \mathrm{CL}$ ) and presence of egg on the pleopod $(61.0 \mathrm{~mm})$ respectively (Thangaraja, 2011). This probably suggests that behavioural maturity (abdomen flexibility) is not synchronized with morphological and functional maturity in females of P. homarus. Positive allometric growth of legs in males and abdomen width in females is definitely advantageous at maturity for which energy is allocated on or before the animals attaining maturity to achieve maximum reproductive success (Anderson, et al. 2013).

Studies on morphometric relationships and relative growth of body parts have been extensively used to interpret the size at maturity in several crustaceans especially to discriminate functionally mature individuals from immature individuals. Though the size at maturity obtained from these relationships is relatively accurate, overestimation/ underestimation of size at maturity will fail to recognize practical stock overexploitation. Two ontogenetic phases are clearly distinguishable in the two sexes of the spiny lobster $P$. homarus homarus by evident morphological changes. The ultimate application of morphometric studies will be useful in resource management of spiny lobsters especially for fixing minimum size limit for capture and for establishing a sustainable fishery management plan.

\section{Acknowledgements}

The authors thank the Director, Central Marine Fisheries Research Institute, ICAR for providing facility to carry out the study. We also acknowledge the help rendered by Dr. J. Jayasankar, Senior Scientist of CMFRI in statistical computations/analysis.

\section{References}

Anderson, J., J. Spadaro, J. A. Baeza and D. Behringer. 2013. Ontogenetic shifts in resource allocation: colour change and allometric growth of defensive and reproductive structures in the Caribbean spiny lobster, Panulirus argus. Biol. J. Linn. Soc., 108: 87-98.

Al-Marzouqi, A., A. Al-Nahdi, N. Jayabalan and J. C. Groeneveld, 2007. An assessment of the spiny lobster Panulirus homarus fishery in Oman - Another decline in the Western Indian Ocean? J. Mar. Sci., 6(2): 159-174.

Berry, P. F. 1970. Mating behaviour, oviposition and fertilization in the spiny lobster Panulirus homarus (Linnaeus). Oceanogr. Res. Inst., (Durban), Invest. Rep., 24: $1-16$.

Berry, P. F. 1971. The biology of the spiny lobster Panulirus homarus (Linnaeus) off the east coast of southern Africa. Oceanogr. Res. Inst. (Durban), Invest. Rep., 28.1-75.

Berry, P. F., 1974. A revision of the Panulirus homarus - group of spiny lobsters (Decapoda, Palinuridae). Crustaceana, 31-42.

Berke, S. K. and A. Woodin. 2008. Energetic costs, ontogenetic shifts and sexual dimorphism in spider crab decoration. Functional Ecology, 2:1125-1133.

Claverie, T. and I. P. Smith. 2009. Morphological maturity and allometric growth in the squat lobster Munida rugosa, J. Mar. Biol. Assoc. U. K., 89:1189-1194.

Crawford, D. R. and W. J. J. De Smidt. 1922. The spiny lobster, Panulirus argus, of southern Florida: its natural history and utilization. Bull Bur. Fish. (U.S.). 38: 281-310.

De-Martini, E. E., G. T. D. Nardo and A. H. Williams. 2003. Temporal changes in population density, fecundity and egg size of the Hawaiian spiny lobster (Panulirus marginatus) at Necker Bank, Northwestern Hawaiian Islands. Fish. Bull., 101: 22-31.

Farmer, A. S. D. 1974. Reproduction in Nephrops norvegicus (Decapoda: Nephropidae), Journal of Zoology, 174: 161- 183.

Fielding, P. J. and B. Q. Mann. 1999. The Somalia inshore lobster resources: a survey of the lobster fishery of the North Eastern Region (Puntland) between Foar and Eyl during November 1988. IUCN, Nairobi, 35pp.

George, R. W. and G. R. Morgan. 1979. Linear growth stages in the rock lobster (Panulirus versicolor) as a method for determining size at first physical maturity. Rapp. P.-v.reun. Cons. int. Explor. Mer. 175: 182-185.

Gomez, G., R. Voigt. and J. Atema. 1994. Frequency filter properties of lobster chemoreceptor cells determined with high-resolution stimulus measurement. $J$. comp. Physiol., 174, 803-811.

Hall, N. G., K. D. Smith, S. de Lestang and I. C. Potter. 2006. Does the largest chela of the males of three crab species undergo an allometric change that can be used to determine morphometric maturity? ICES J. Mar. Sci., 63: 140-150.

Hartnoll, R. G. 1965 A new entoniscid from Jamaica (Isopoda, Epicaridea). Crustaceana. 2: 45-52.

Hartnoll, R. G. 1974. Variation in growth pattern between some secondary sexual characters in crabs (Decapoda, Brachyura) Crustaceana, 27:131-136.

Hartnoll, R.G. 1978. The determination of relative growth in Crustacea. Crustaceana, 34:281-293.

Hartnoll, R. G. 1982. Growth In Bliss D.E. and Abele L.G. (eds) The biology of Crustacea. Volume 2. Embryology, morphology and genetics. New York: Academic Press, pp. 111-196.

Hepper, B. T. 1966. Measurement of carapace length and total length in the crawfish, Palinurus vulgaris. J. Cons. perm. Int. Explor. Mer., 30: 316-323.

Heydorn, A. E. F. 1969. The rock lobster of the South African west coast. Jasus Ialandii ( $\mathrm{H}$. Milne- Edwards). 2. Population studies, behaviour, reproduction, moulting, growth and migration. S. Afr. Div. Sea. Fish. Invest. Rep., No. 71: 1-52.

Holthuis, L. B. 1991. Marine Lobsters of the world. FAO species Catalogue, FAO Fisheries Synopsis, Food and Agriculture Organization, Rome 125 (13): 1-292.13.

Jayakody, D. S. 1989. Size at onset of sexual maturity and onset of spawning in female Panulirus homarus (Crustacea: Decapoda: Palinuridae) in Sri Lanka. Mar. Ecol. Progr. Ser., 57: 83-87.

Jeena, N. S. 2013. Genetic divergence in lobsters (Crustaceana: Palinuridae and Scyllaridae) from the Indiann EEZ, Ph. D Thesis, Cochin University of Science and Technology, Cochin, pp-238.

Jones, C. M. 2007. Biology and Fishery of the Bay Lobster, Thenus spp. In: K. L. Lavalli and E. Spanier (Eds.) The Biology and Fisheries of the Slipper Lobster, CRC Press, pp.325-358.

Juinio, M. A. 1987. Some aspects of the reproduction of Panulirus penicillatus (Decapoda: palinuridae). Bull Mar Sci., 41:242- 252.

Lovett, D. L. and D. L. Felder. 1989. Application of regression techniques to studies of relative growth in crustaceans. J. Crust Biol., 9: 529-539.

Lipcius, R. N., M. L. Edwards, W. F. Herrnkind and S. A. Waterman. 1983. In situ mating behaviour of the Spiny lobster, Panulirus argus. J. Crust. Biol., 3 (2): 217-222.

Kabli, L. M. and P. V. Kagwade. 1996. Morphometry and conversion of the sand Iobster, Thenus orientalis (Lund) from Bombay waters. Indian J. Fish., 43: 249254.

Kagwade, P. V. 1987. Morphological relationships and conversion factors in spiny Iobster Panulirus polyphagus (Herbest) from the north-west coast of India. Indian J. Fish., 34 (3): 348-52.

Kizhakudan, J. K. and S. K. Patel. 2010. Size at maturity in the mud spiny lobster Panulirus polyphagus (Herbst, 1793). J. Mar. Biol. Ass. India, 52(2): 170-179.

Kulmiye, A. J., K. M. Mavuti. and J. C Groeneveld. 2006. Size at onset of maturity in spiny lobsters Panulirus homarus homarus from Mambrui, Kenya. Afr. J. Mar. Sci., 28: 51-55.

Minos, G., G. Katselis, P. Kaspiris and I. Ondrias. 1995. Comparison of the change in morphological pattern during the growth in length of the grey mullets Liza ramada and Liza saliens from western Greece. Fish. Res., 23: 143-155.

Minagawa, M. and S. Higuchi. 1997. Analysis of size, gonadal maturation and functional maturity in the spiny lobster Panulirus japonicus (Decapoda: Palinuridae). J. Crust. Biol., 17:70-80.

Radhakrishnan, E. V. and M. K. Manisseri. 2003. Lobsters. In: M.M. Joseph and A. Jayaprakash (Eds.) Status of exploited marine fishery resources of India. Central Marine Fisheries Research Institute, Kochi, India, pp.195-202.

Sanders and Liyanage. 2009. FAO Fisheries Report. Report of the regional workshop on the assessment of the caribbean spiny lobster (Panulirus argus) FAO/ DANIDA/ CFRAMP/ WECAFC. Fisheries Report No.619. 
Saha, S. N., P. Vijayanand and S. Rajagopal. 2009. Length-weight relationship and relative condition factor in Thenus orientalis (Lund, 1793) along East Coast of India. Current Res. J. Biol. Scie., 1(2): 11-14.

Smith, I. P., F. A. Huntingford, R. J. A Atkinson and A. C Taylor. 1994. Mate competition in the velvet swimming crab Necora puber: effects of perceived resource value on male agonistic behaviour. Mar. Biol., 120: 79-585.

Tidu, C., R. Sarda, M. Pinna, A. Cannas, M. F. Meloni, E. Lecca and R. Savarino. 2004. Morphometric relationships of the European spiny lobster Palinurus elephas from northwestern Sardinia. Fish. Res., 69: 371-379.
Thangaaraja, R. 2011. Ecology, reproductive biology and hormonal control of reproduction in the female spiny lobster Panulirus homarus (Linnaeus, 1758). Ph.D Thesis. Mangalore University, India. pp-172.

Vaitheeswaran, T., N. Jayakumar and V. K. Venkataramani. 2012. Length weight relationship of lobster Panulirus versicolor (Latreille, 1804) (Family: Palinuridae) off Thoothukudi waters, southeast coast of India. Tamilnadu J. Veterinary \& Animal Sci., 8 (1):54-59.

Zar, J. H. 1999. Biostatistical Analysis, 4th Edn. Prentice-Hall, Upper Saddle River, New Jersey. 663pp. 